\title{
山形県大石田町における歴史的町並みを保全した 町づくりに関する研究
}

\section{A Study on the Conservation of the Historical District at Ohishida Town in Yamagata Prefecture}

\author{
温井 亨*
}

\section{Tohru NUKUI}

\begin{abstract}
摘要：本研究の目的は，山形県北村山郡大石田町の中心市街を事例として取り上げ，歴史的町並みを 残しつつも，既に建て替えも進んでいる町並みでの町づくりの方法を探ることである。そのために現 存する町家を実測調查し、敷地と建築がセットになった単位を敷地建築類型と名付け類型化し分析し た。その結果, 歴史的な敷地建築類型に共通するのは, 建物を北西側に寄せ, 南東側に庭を設けて通 風・採光をとるという住環境維持の仕組みであり，今後の町づくりにも適用可能なことを示した。ま た, 街路景観の保全についても，街路に面する庭という類型の特徵を活かした整備か，町家のファサー ド修復とともに有効であることを示した。
\end{abstract}

\section{1.はじめに}

本研究の目的は，山形県北村山郡大石田町の中心市街を事例之 して取り上げ，歴史的町並みを残しつつも，既に建て替えも進ん でいる町並みでの町づくりの方法を探ることである。大石田町の 歴史的市街は最上川の河岸として発展し，短冊型の敷地之町家に よる町並みを特徴とするが，既に建て替えられた建物も多い。し かしながら近年, 人口減少, 商店街としての活力低下に対して, 歴史的町並みの保全を軸とした町づくりを模索し始めている。 1960 年代以降の建て替えや增改築が，ファサードを陸屋根に見 せるような洋風化近代化を指向したのに対して，現在ではロード サイドの郊外型大型店に対抗するために，郊外型大型店にない魅 力として，自らの歴史と文化に目を向けつつある。

平成 5（1993）年に大石田町商工会と大石田町本町商店振興会 がまとめた商店街活性化計画「最上川舟運文化発祥の商店街づく り」’ は，歴史を活かした町づくりの最初の提案である。平成 9 （1997）年に日本建築学会が文化庁の委託を受けて行った「歴史 と文化のまちづくりへ」2〉 と題する報告では，大石田町中心部の 歴史的町並みが事例調查地の 1 つに選ばれ，登録文化財制度の活 用等による歴史を活かした町づくりが提案された。大石田町は翌 年，それを受けて街並保存検討委員会を組織し，現存する歷史的 建築の実測調查等を行い「大石田町街並保存検討報告書」3) を作 成している。

筆者は日本建築学会の調査之, 翌年の大石田町の調查に参加し ているが，本研究は両調査のデー夕を使い，建築と敷地の類型化 により，主として住環境という視点から町並みを分析し，歴史的 市街の町づくりの方法を探る。住環境という視点を取るのは，大 石田町のような既に建て替えの進んだ市街では，文化財の保存之

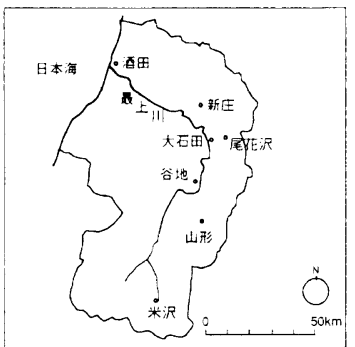

図-1 山形県と大石田の位置
いう論理ではカバーしきれな い問題も多く，また住民の合 意形成を図るための論理とし ても不十分と考えるからであ る。そこで，歴史的市街保全 が住環境の上からあ優れてい ることを示し，それによって 町並み保全の合意形成を図れ たらと考えるのである。歴史 的市街が住環境を保つ仕掛け
を持っていることは, 関西の町家等では論じられているが, 東北 に於いてはこれまでほとんよ゙論じられていない。

なお, 保全型の町づくりに先行する調查研究として, 建築史の 立場から, 高橋恒夫氏による河岸場集落と職人集団としての大石 田の歴史的分析 ${ }^{4}$ がある。

\section{2. 歴史的町並みの概要}

次に大石田町中心部の歴史的町並みの概要を説明する。

大石田町の歴史的町並みは, 図 1 のように最上川の河岸として 形成された港町であり，一時的な衰退時期はあるものの，17 世 紀初めから明治まで, 最上川舟運の内陸最大の拠点であった。図 2 に, 本研究で扱う歴史的町並みの範囲を示すが，ここでは 17 世紀初めに町割りが行われ, 川と平行する大通りの両側に町家が 並ぶ市街が形成された。住民構成の特徴を記せば，かつての旦那 衆の大きな店は中央部に多く, 四日町之呼ばれる北西部や，川端 町と呼ばれ大通りに面しない南東部には，大工や左官等の建築職 人が多い。建築職人が多いのは, 町家の並ぶ高密度居住に由来す る火災や, 最上川の洪水による家屋の損壊の頻発に由来し, 江戸 時代以来のものである。

大石田の舟運は明治 34（1901）年に奥羽線が通じると衰退し たが，荷問屋等の有力な商人はこの時期に地主化し，かえってこ れ以降昭和初期に，周囲の敷地を併合した間口の大きな屋敷がつ くられた。戦後は地主層が解体し, また後継者の町外への転出, 郊外型大型店の進出により, 商店街としての衰退が問題となって いる。中心部の町並みが歴史的面影を良く残しているのは, 舟運 衰退後の交通機関である鉄道（奥羽線）も幹線道路（国道 13 号） も旧市街をはずれたからである。

気候，災害上の特徴として町並み保全に関係するのは，しばし ば積雪 $2 \mathrm{~m}$ を越える豪雪であり，また，かつては洪水，火災が頻 発した。最後の大水害は特殊堤建設前の昭和 44 (1969) 年, 最 後の大火は明治 37 (1904) 年であり, 現在残る建物は一部の土 蔵を除き明治以降の建築である ${ }^{56677}$ 。

都市計画的には建蔽率 80\%, 容積率 200\%であり, 近隣商業地 域に指定されているが，防火系の地区指定はされていない。現状 の法定都市計画は, 現在同市街が必要としている課題に応えるに は不十分である。なお, 中心市街を縦断する本町通りの拡幅が都 市計画決定されていたが, 平成 10（1998）年に街並保存検討委

*東北芸術工科大学デザイン工学部環境デザイン学科 


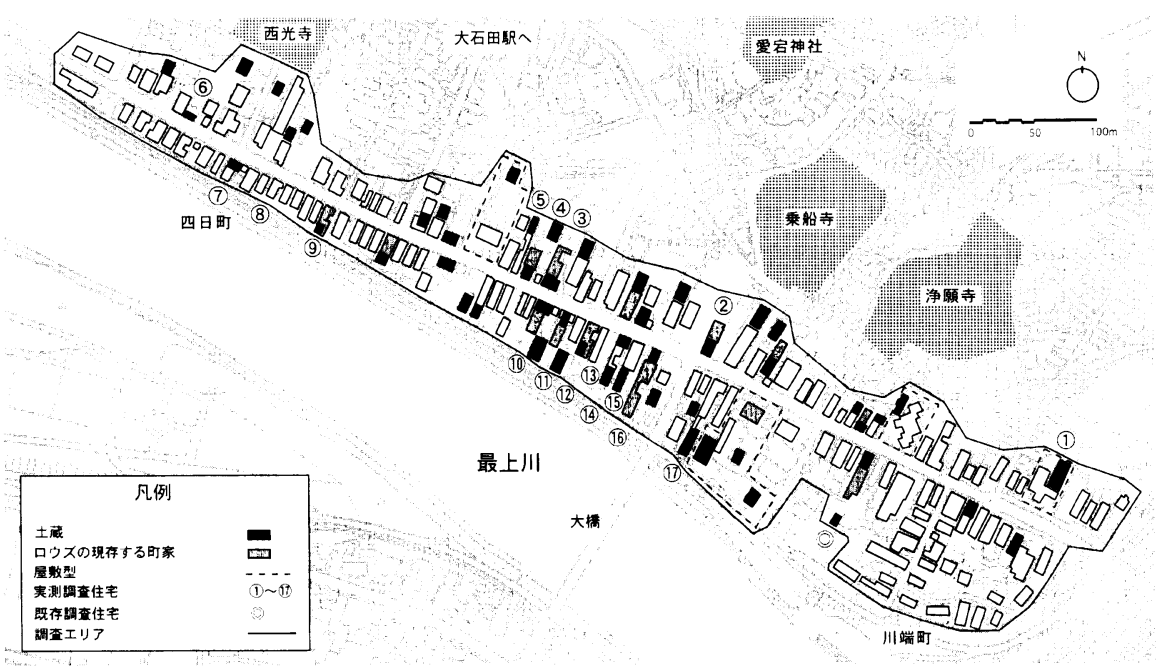

図-2 歴史的町並みの概要

員会が拡幅撤回を答申し，現在は町も現状幅員での整備を考えて いる。

本研究で考察の対象とするのは，平成 9 (1997）年 9 月に行わ れた街並保存検討調査に於ける歴史的建築とその敷地の実測調查 の結果であり，図上に(1)〜17で示す。これらの選定基準は，歴史 的市街（図に示した調査エリア）内の全 117 户を対象に行ったア ンケート調查（同年 8 月に実施）等から，歷史的建築であること， 敷地が連続していること，類型の違い，地区による違いなどを勘 案して決定した。具体的に選定の手順を述べれば，まず，歴史的 建築が連続している場所として, 川側に10～16が並ぶ所, 川と逆 側に(3)〜(5)が並ぶ所を見出し，計 10 棟の実測を行った。この中 には歴史的建築でないものもあるが, 研究目的が住環境にあるの で比較のために調查した。また，連続はしていないが歴史的建築 として, (2)と(17)の 2 棟を調查した。一方, 屋敷型の類型として(1) を，地区としての性格の違いを見るために北西部から(6) (9)を選 んだ。ただし同地区に残る歴史的建築は少なく, 建物の全体が残つ ているのは(9だけである。また，図上(○で示す建物は歴史的建築 であるが，すでに高橋恒夫氏によって実測が行われ実測図が報 告䄈されているので，今回は改めて実測は行わず同資料を考察に 用いた。

図より明らかなように大石田町中心部の歴史的市街には土蔵が 数多く現存する。地区の複数の高齢者からのヒアリングによれば, 戦後の時点では現在の倍の土蔵があったと言う。一方，土蔵以外 の部分は建て替えが進み, 現在建物全体が残っている町家は少な

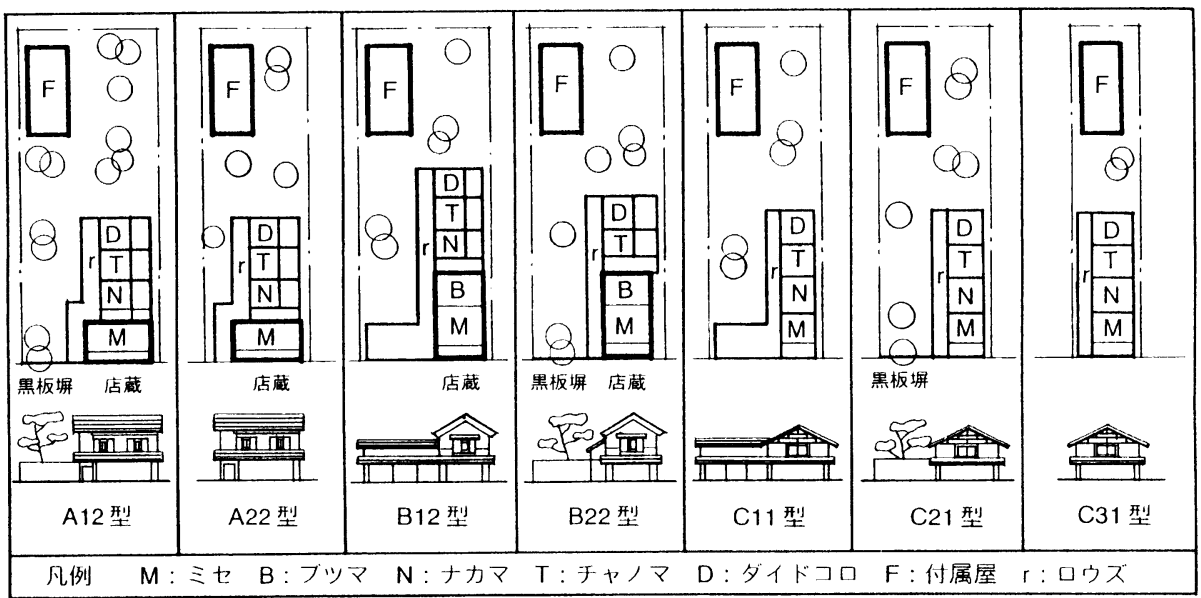

図一３歴史的な敷地建築類型
い。前述の高齢者からのヒアリングに よれば，かつては中心部の歴史的市街 の全ての家屋は町家であり，「ろう ず」8〉 と呼ばれるトオリニワを持って いた。図に現在であろうずを維持して いる家屋を記す。実测対象を選ぶ際の 歴史的建築の基準は，ろうずの有無を 重視している。

\section{3. 歴史的敷地建築類型}

実測調査の結果から類型化を行うが, その際, 敷地と建築がセットになった 単位を考え，それを敷地建築類型と名 付ける。類型化する要素は, 敷地とそ の上の建築, 庭, 荆であり, その配置, 1 階平面図を類型化して平面の類型と し，立面を類型化して立面の類型とす る。図 3 に, 実測調査から抽出した大 石田町中心部の歴史的な敷地建築類型を掲げる。この 7 類型で大 石田町中心部の歴史的な敷地建築類型は尽くされていると考えら れるが, 例外は屋敷型である。これは昭和初期に周囲の敷地を併 合して成立した類型であるが, 本研究では分析の対象に加えなかっ た。その理由は, 調査できた屋敷型の改変が大きく十分な分析が 行えないこと, 住環境維持の仕組みという点では, 敷地に余裕の ある屋敷型の環境が良いのは自明であることによる。さて, 四に 掲げた歴史的な敷地建築類型の特徵は以下の通りである。

まず，平入りの店蔵を持つ類型を A 型としてまとめる。 $\mathrm{A} 12$ 型は，店蔵の脇に黒板塀がつく類型である。立面に見えている樹 木は，しばしば通りに被さっていたことが現存する事例，ヒアリ ング, 古写真 ${ }^{97}$ から分かる。店蔵の 2 階は荷蔵の場合之蔵座敷の 場合がある。ろうずは倠行し, 奥の諸室は 2 列型となる。大石田 町中心部の歴史的建築では, 通りに面する建物がヨコ屋（棟が通 りと平行）であれ夕テ屋（棟が通りに直交）であれ，奥につづく 部分は常に夕テ屋となる。万うずに面する奥の諸室は, 店蔵側か ら,ナカマ, チャノマ, ダイドコロと呼ばれることが多い。

A22 型は A12 型に似るが，店蔵脇の黑板垪がない。その分だ け間口が狭い。

B 型は, 妻入りの怎蔵が通りに面する類型である。店蔵は 2 階 建てであり， 2 階は荷蔵である場合と, 蔵座敷の場合がある。1 階はもともと 2 室に分かれ, 通り側がミセ ${ }^{107}$, 奥がブッマと呼ば れる場合が多い。ミセの手前，下屋庇の部分はコマヤと呼ばれる。 もともとは座売りであり, ミセは座敷であったが, 現在は蔵全体 を土間化している店も多い。逆に ミセを座敷のままにしている家は 商売を止めて住宅化している家で ある。奥の諸室はろうずに沿って ナカマ, チャノマ, ダイドコロと 3 室の場合之, チャノマ, ダイド コロと 2 室の場合がある。後者の 場合は, 蔵のブッマがナカマの役 割を果たしていると考えられる。 B12 型は, 妻入りの蔵の脇にヨ コ屋の店が付加されたタイプであ る。現存する 1 軒は奥の諸室 2 列 型である。この類型は通りに面し て付加されたヨコ屋の分, 間口が 広く庭を持つ。

B22 型は, 妻入の店蔵の脇にも 
ともと黒板塀が付いていた類型だが, 現存する事例に塀はなく全 て車庫となっている。所有者からの聞き取りにより, かっては黒 板垪越しに樹木が通りに被さっていた場合のあることが分かる。 調査した住宅の奥の諸室は 2 列型（梁間 4.5 間）が多かったが,

1 軒では 1 列型と 2 列型の混合（梁間 4 間）であった。

C 型は通りに面した蔵を持たない類型であり, 全て建築全体が 通りに対して夕テ屋, 妻入りとなっている。このうち C11 型は, 妻入りの主要部分に, 通り側だけョコ屋が付加された形である。 現存する 1 棟は職人の住まいであり, ヨコ屋部分も含めて通り側 全体が仕事場になっている。奥の諸室は 1 列型であり, 通り側か らナカマ, チャノマと呼ばれている。ヨコ屋のある分が庭となる。

C21 型は脇に黒板塀がつく類型である。かつては塀の脇まで庭 で, そこに樹木があったと考えられるが, 現存の 1 棟は車庫になっ ている。奥の諸室は 1 列型である。

C31 型は敷地間口いっぱいに建っている類型である。現存する 1 棟は間口 3 間 1 列型で, 総 2 階建てに改築され居室を 2 階に設 けている。

\section{4. 住環境維持の仕組み}

図 4 に掲げる(10～(16)の連続平面図を用いて，大石田町中心部の 歴史的市街に於いて住環境がどのように確保されてきたのか, 店 のゾーン, 居室のゾーン, 畑・庭のゾーンの 3 つに分けて考察す る。図は網掛けで示す増築部分を含むが，ここで分析するのは増 築部分を含まない当初の平面である。

まず店のゾーンであるが，ここは住環境より生業が優先される と推測される。したがって通常町家の場合, 間口いっぱいに使う のが一般的だが, No.2, No.6, No.9の場合, 黑板啹がまわり 庭の樹木が見えたことが分かる（No.9 はマッが現存，他はヒア リングで確認)。ただし店との間は壁であり，店が通りだけに開 かれるのは一般の場合と変わらない。また, No.2の妻入りの店 蔵にはかつてブッマがあり, 蔵特有の閉鎖的な部屋となっている。 しかし，図にはないが同様なっくりでも，(2)(4)（図2）では口ウ ズ側に屝を設けた開放的な座敷となっていて, 蔵のブッマの中間 的な性格が伺える。

次に住環境と最屯関係する居室ゾーンについて考える。网では 現存する 5 棟の町家とも南東側にろうずを持ち（No.4 は畳に改 築), 建物を北西側に寄せ， 万うずの前に庭（空地）をつくる （No.2 は例外）というほぼ共通した配置を備えている。これは 通りから奥へ向かって 4 5 室が並ぶ大石田の町家にとって, 中 ほどのナカマ, チャ/マへの通風・採光は, どうしても側面から 入れざるを得なくなるからであり，住環 境確保の必要から守られてきた歴史的な 約束事だと考えられる。ただし類型によっ て違いがあり，黒板塀のまわる類型であ るA12 型(No.9), C21 型（No.6）が 最屯通風・採光条件が良く, 次いでョコ 屋がつく B12 型（No.8）が続き，A22 型（No.4）はろうずの倠行分でかろう じて空地を確保していることが図から読 みとれる。

最後に畑・庭のゾーンであるが，ここ は基本的に緑の多い空間となっていて, 歴史的市街の住環境に寄与している。付 属屋や，また離れ之見なされる蔵座敷な ぞもあるが，その場合もNo.9のように， 主屋とは逆の隣地境界線に寄せて建てる などして，主屋居室への通風・採光を確 保する場合が多い。

\section{5. 増改築と今後の展開}

戦後になると増改築や建て替えにより歴史的な敷地建築類型が 崩れ, 町並みが変化する。そこで, 図 4 に増築部分を網掛けで示 し，増築・建て替えによる市街の変化を以下のようにパターン化 して分析する。調査エリアに見られる増築パターンは図中にほと んよ゙見出される。

まず，第 1 のパターンは，通り側の黒板塀が廻っていたところ に増築するパターンである。図で，No.2，No.6，No.8はここ に車庫を增築している。この中には, 車庫の 2 階に居室の增築も 併せて行った例もある。また, No.9 は昭和 2 年に洋館を増築し ている。現存する 1 本のマッは塀越しの庭の名残之見られる。

第 2 のパターンは 2 階の增築である。歴史的な町家のつくりは 蔵以外が平家だが，それを 2 階建てとするものである。No.4が それに当たり，店蔵の奥の諸室を総 2 階化している。No.4では 隣が空地であるので問題ないが,このパターンは隣家の採光への 影響が危惧される。

第 3 のパターンは裏への増築である。眓ではNo.2 が, 菓子工 場と居室を裏に増築している。しかしながら，No.6のように裏 にすぐ続いて蔵がある場合には，このような増築パターンが行え ない。そこで第 4 のパターンとして, 裹側側方への増築がある。 No.6は,このパターンの増築である。

一方，建て替えの場合は 3 パターンある。一つはNo.3に見ら れる歴史的な敷地建築類型に倣った建て替えである。 こつ目のパ ターンはNo.5, No.7に見られる総 2 階化，三つ目はNo.1 に 見られる庭付き一戸建て型である。

次に，歴史的な市街が持っていた住環境維持の仕組みと,ここ で述べたその変化の分析を踏まえて, 今後の町づくりへの展開を 考える。歴史的な敷地建築類型は，主屋を北西側に寄せ，南東側 にロウズと庭を設けて通風・採光を図るという優れた住環境維持 の仕組みを持っていた。戦後, 増築が行われるが, 前述の 3 パ夕一 ンとも居室ゾーンには手を付けず，歴史的な仕組みを活かしてい る。この考え方は今後の町づくりに於いても引き継いで行くべき と考える。ただし， 3 パターンを吟味すると，屯ともと利用度の 低い畑・庭ゾーンへの増築は妥当と考えられるが， 2 階への增築 は隣家への影響に注意を要する。また，店ゾーンでの増築は住環 境上は影響が少ないが，街路景観として問題があり，これは別に 論じる。建て替えについても同様で, 歴史的な敷地建築類型に倣っ た建て替えは住環境上問題ないが，2階建て以上にする場合は増 築之同様隣家への問題がある。また，庭付き一戸建て型は本来郊 外住宅地の敷地建築類型であり, 商店街・中心市街としての賑わ

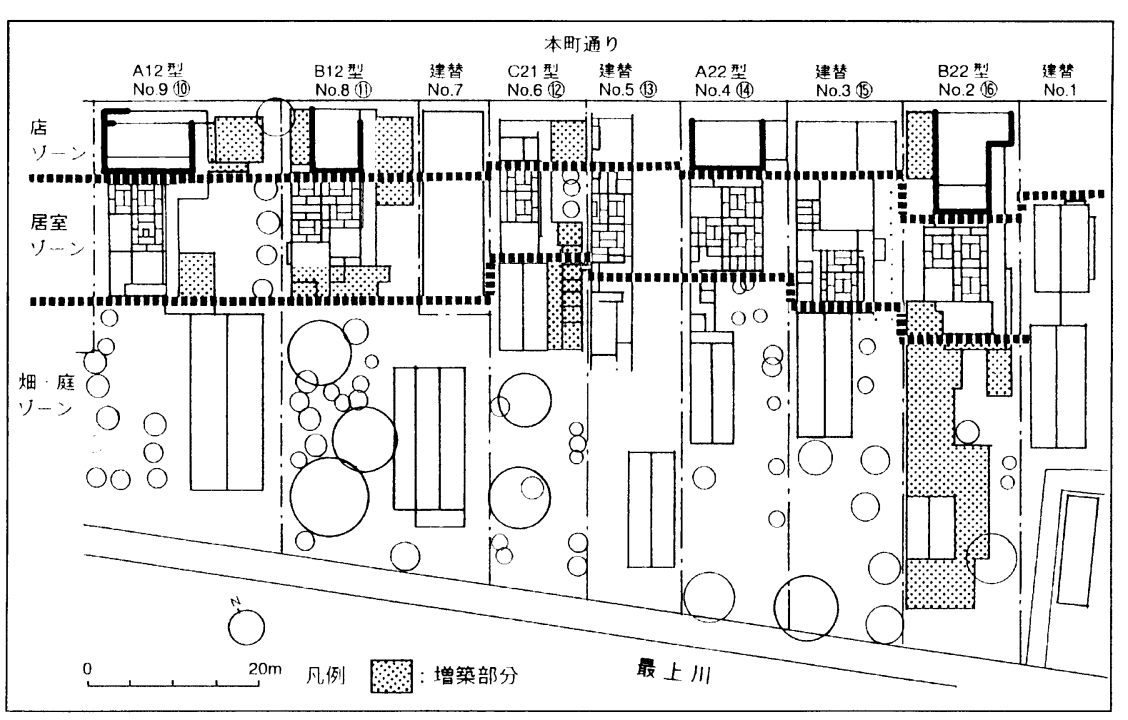

図ー4 歴史的町並みにおける住環境維持の仕組み 


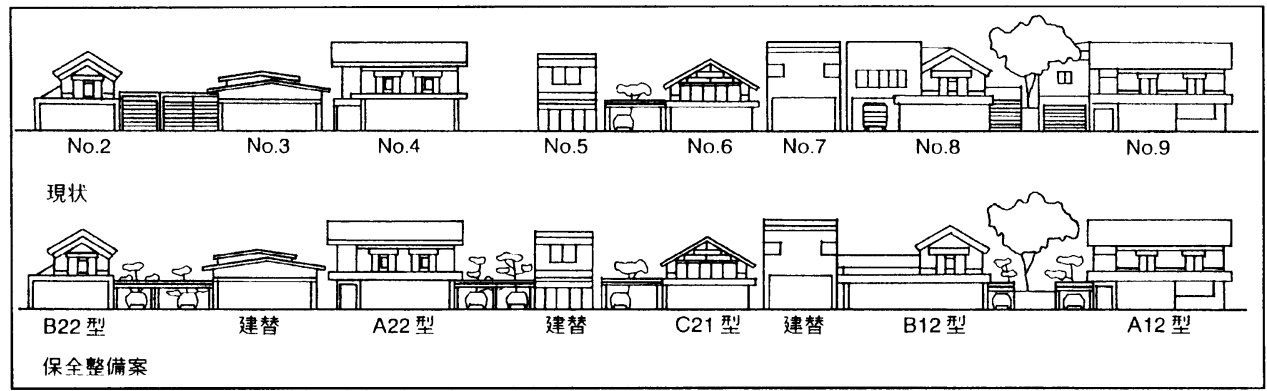

図- 5 街路景観の保全
南東側に庭（空地） を設けているのは, 以上のような住環境 上の工夫のためだと 考えられる。大石田 ではこの庭（空地） がしばしば通りにま で及び，黑板地越し に庭の樹木が通りに 被さることああった。 住環境上の必要性
いを奪うことに繫がる。

図 5 は，図 4 に掲げた市街の通り側連続立面図である。これを 使って店ゾーンでの増築と街路景観の問題を考える。まず，現状 四を見ると，歴史的な 5 棟がバラバラで，連続した町並みが感じ られない。それは 5 棟の間に建て替えられた店舗が割り込んでい るためでもあるが，もう1つの理由は，5棟自らが車庫等を増築 して自らの姿を目立たなくしているためである。そこで今後の町 づくりとしては，歴史的なファサードの特徽がはっきりわかるよ うな修復が望まれる。保全整備案は，部分的改築や増築部分の除 去によって，どこまで修景可能かを検討している。まずNo.2 と No.3 の車庫を, シャッターから壁無しの開放型に变更する。こ れはNo.6の住宅が既に行っている車庫のつくりで，壁を設けず 柱だけで屋根を支持する方法であり，奥の庭の緑が通りからも伺 われ，住環境からも庭へ風が抜け好ましい。No.4の平入りの怎 蔵では，屋根を背後への片流れから切妻に戻す。No.8の妻入り の店蔵では，車庫を開放型に直すことと，脇の 2 階建ての増築部 を取り除けば，当初の B12 型に戻すことができる。No.9でも， 脇に増築した洋館部分を取り除くことにより，店蔵を際だたせる ことができる。

こうして，大石田の歷史的町並みの特徴であったファサードの 多様さ（ 5 棟の歴史的立面の類型が全て違う），通りから見える 緑の多さ（歴史的類型 A12 型，B22 型，C21 型の特徵）を，車 庫などの現代生活に必要なあのは残しながら，再び取り戻すこと ができる。

\section{6. まとめ}

大石田町中心部の歴史的町並みでは，平入りの店蔵を別にして, 主屋は通りに対して一続きの夕テ屋で形成される。したがって, 細長い家屋の中央部の部屋には，側面から通風・採光を図るしか 方法がない。歷史的な敷地建築類型が全て建物を北西側に寄せ,
に由来する以上の敷地建築類型，またその現れである通りから見 える樹木という特徴は, 町割りが変わらない限り, 大石田中心部 の町並みにとって普遍的な解であり続ける。したがって，今後の 町づくりに於いても尊重されるべきルールだと考える。一方では ロウズのように，豪雪故の必要性は変わらないが，生業の変化に よって姿を消したものむある。その場合には文化財として現存す るものの保存は検討すべきだが，無くなったものの復元までは必 要ないと考える。ファサードについても同様で，元々の町家の特 徵を消している増築部分は除去し, 改変された所の修復は検討す べきだが，建て替えで失われたものまで復元する必要はない之考 える。ただし，現在の店舗の意匠，素材は，町家とあまりにもか け離れて不調和であり，対策が必要である。その点で参考になる のは県内の金山町で，同町では真壁風白壁づくり腰下見板張りの 住宅を奨励している。これは町家より後の昭和 30 年代頃までの 住宅がモデルと思われるが，現在でも採用しやすいつくりであり， 大石田であ参考になる。

以上は，町家が比較的数多く現存する調查エリア中央部での実 測調查から得た結論であるが，原理的には短冊形の敷地からなる 調查エリア全域で成り立つと考えられる。しかしながら，以下の 2 点で課題を残す。まず，敷地間口が狭く，側面に空地を取れな いC31 型の住環境の扱いであり，実測調査では一例（図 2 (5) だけであったが，まず調查エリア全体での棟数から調べる必要が ある。また，北西部の四日町で今回調査した8)の住宅は，総 2 階 建てに建て替えているが，奥行き方向に 3 部屋が並ぶだけであり， これだと中の部屋を続き間とすれば，通り側と川側から通風・採 光できるため側面の空地は必要性が少ない。この場合は間口が狭 くても住環境を確保できると考えられるが，奥行き方向への増築 は控える必要があり，1つの類型として検討する必要がある。以 上は, 今後調査エリアの両側の地区で，建て替えられた住宅の調 査も補足して行う必要性のあることを示唆している。

\section{注と参考文献}

1) 本町街づくり委員会（1993）：大石田 町本町商店街活性化計画策定事業報告 書一最上川舟運発祥の商店街づくり一： 大石田町商工会, 大石田町本町商店街 振興会

2 ）日本建築学会街並み景観調查研究委員 会 (1997)：我が国における街並み景 観の在り方調査研究報告書一歴史之文
化のまちづくりに向けてー：(社)日本 建築学会

3 ) 温井亨 (1998)：大石田町街並保存検 討報告書 : 大石田町

4 ) 高橋恒夫 (1995)：最上川水運の大石 田河岸の集落と職人 : 大石田町

5 ) 長井政太郎 (1973)：大石田町誌（復 刻版）：中央書院

6 ）大石田町（1985）: 大石田町史（通史
編上卷）：大石田町

7 ）大石田町（1993）: 大石田町史（通史 編下巻）：大石田町

8 ) 京都方言「ろ一じ」の転叱と思われる。

9）大石田町 (1986)：写真でみる大石田の あゆみ（通史編別巻）：大石田町

10）商店の意味で店, 大石田で使う部屋名 としてはミセと書き分け区別する。

Summary: The aim of this study is to seek how to conserve the historical district where traditional houses have already rebuilt considerably, investigating the typology of the traditional town houses at the core district of Ohishida Town in Yamagata Prefecture. The results are as follows: 1) Generally in historical site-building types of Oishida, there is the device to maintain a dwelling environment. They have built their houses around northwest side of the site and as a result on the other side they have a court for ventilation and daylighting. This system is useful for the town planning of this district also nowadays. 2) For the conservation of the streetscape, it is useful to restore the court which has faced the street, besides the restoration of the façade of traditional town houses. 